\title{
Haemolytic uraemic syndrome: therapeutic effect of plasma infusion
}

\author{
ROCCO MISIANI, ALDO CLARIS APPIANI, ALBERTO EDEFONTI, ELIANA GOTTI, \\ ALBERTO BETTINELLI, MARISA GIANI, EDOARDO ROSSI, GIUSEPPE REMUZZI, \\ GIULIANO MECCA
}

\begin{abstract}
The therapeutic effect of plasma infusion was evaluated in 10 children and seven adults with haemolytic uraemic syndrome. All but one patient responded to this treatment with rapid disappearance of haematological abnormalities. The patient who apparently failed to respond to plasma infusion obtained complete remission of the disease after plasmapheresis. Although 15 of the 17 patients were anuric or oliguric on admission, renal function recovered completely in eight children and two adults. Seven patients showed residual chronic renal failure and two required long-term maintenance haemodialysis. Treatment with plasma was also successful in patients with relapses or recurrent episodes.

Plasma infusion is a promising therapeutic approach for the haemolytic uraemic syndrome and deserves further study in clinical trials.
\end{abstract}

\section{Introduction}

Haemolytic uraemic syndrome is characterised by microangiopathic haemolytic anaemia, thrombocytopenia, and renal failure. Histological examination shows thrombotic occlusions in the microcirculation, the kidney being the main target organ.

The pathogenesis has been ascribed to localised intravascular coagulation, ${ }^{1-3}$ and heparin ${ }^{45}$ and fibrinolytic agents ${ }^{6} 7$ have been used. Studies of platelet survival and fibrinogen turnover, however, have indicated that intravascular platelet aggregation is an important step in the pathogenesis, ${ }^{8} 9$ thus supporting the use of antiplatelet agents. ${ }^{1011}$ As yet none of these treatments has proved entirely effective.

The haemolytic uraemic syndrome shares many characteristics with thrombotic thrombocytopenic purpura, and similar pathophysiological mechanisms are suspected for both diseases. ${ }^{12}$ Some reports have drawn attention to the beneficial effect of exchange transfusion and plasmapheresis in thrombotic thrombocytopenic purpura, ${ }^{13-15}$ and Bukowski et al have suggested that these procedures may act by removing antibodies, immune complexes, or other undefined toxic substances. ${ }^{15}$ Remission in a patient with thrombotic thrombocytopenic purpura using plasma infusion alone ${ }^{16}$ however, suggested that the infusion replaced a missing factor, possibly a physiological

\footnotetext{
Division of Nephrology and Dialysis, Ospedali Riuniti di Bergamo, Bergamo, Italy

ROCCO MISIANI, MD, physician

ELIANA GOTTI, MD, physician

GIUSEPPE REMUZZI, MD, physician

GIULIANO MECCA, MD, physician

Dialysis Unit, Clinica Pediatrica II, University of Milan, Italy ALDO CLARIS APPIANI, MD, physician ALBERTO EDEFONTI, MD, physician ALBERTO BETTINELLI, MD, physician MARISA GIANI, MD, physician

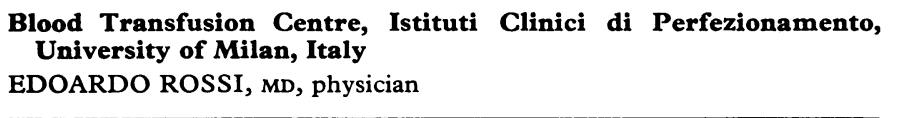

inhibitor of platelet aggregation. This suggestion received $\frac{\overline{\bar{N}}}{\overline{5}}$ support from studies ${ }^{17-20}$ indicating that plasma from patients $\frac{\vec{\sigma}}{\sigma}$ with thrombotic thrombocytopenic purpura or haemolytic $\unrhd$ uraemic syndrome lacks a factor which normally stimulates the release of vascular prostacyclin $\left(\mathrm{PGI}_{2}\right)$. In some of these $\vec{\circ}$ patients infusions of normal plasma corrected the plasma factor defect and induced remission. We report here the results of $\vec{\omega}$ treatment with plasma infusion in 17 patients with haemolytic $\frac{\mathscr{S}}{\circ}$ uraemic syndrome.

\section{Patients and methods}

We studied 10 children aged 9 months to 8 years and seven adults. (aged 14 to 61 years) admitted to hospital over two years. The diagnosis $\vec{\omega}$ of haemolytic uraemic syndrome was based on the classic findings of $\square$ microangiopathic haemolytic anaemia, thrombocytopenia, and renal 음 failure. Microangiopathic haemolytic anaemia was defined as a drop $\sigma$ in the packed cell volume in the absence of bleeding together with $Z$ reticulocytosis, a low or undetectable serum haptoglobin concentration, and the presence of fragmented erythrocytes in the blood smears. $\frac{\mathbb{D}}{3}$ Renal biopsy was performed in 14 patients. Histological examination by immunofluorescence and light microscopy confirmed the diagnosis of haemolytic uraemic syndrome in all cases.

To evaluate the effect of treatment the following criteria were adopted: haematological response-increased platelet count or ${ }^{\text {N }}$ reduced signs of microangiopathic haemolytic anaemia (decreased serum lactate dehydrogenase and number of fragmented red blood cells; increased serum haptoglobin), or both; haematological remission -return of the platelet count to normal $\left(150 \times 10^{9} / 1\right)$ and disappearance of all signs of microangiopathic haemolytic anaemia; renal response- $-\frac{\mathrm{D}}{\mathrm{D}}$ improved renal function and reduced urinary abnormalities; and 2 complete remission-correction of all haematological and renal $\overrightarrow{\bar{O}}$ abnormalities.

All patients were treated with plasma infusion according to the following schedule. During the first session of haemodialysis or over eight hours in patients not undergoing dialysis, we administered a loading dose ( 30 to $40 \mathrm{ml} / \mathrm{kg}$ ) of fresh-frozen plasma; then a plasma infusion of 15 to $20 \mathrm{ml} / \mathrm{kg}$ was given daily until haematological remission occurred. The same schedule of treatment was used for $\bar{\sigma}$ early relapses and recurrent episodes. Plasmapheresis was used in one patient (case 10) who did not appear to benefit from plasma infusion. This patient was treated by exchanging $40 \mathrm{ml} / \mathrm{kg}$ of her $\supseteqq$ plasma for fresh-frozen plasma on alternate days until haematological 0 remission was achieved. Whole blood or packed red blood cells were given when the packed cell volume was below $0 \cdot 25$. Fourteen patients $N$ needed haemodialysis.

Four patients received antihypertensive drugs: atenolol, prazosin, $\frac{\mathrm{D}}{\mathrm{O}}$ dihydralazine, clonidine, frusemide, and nifedipine.

\section{Results}

Clinical and laboratory data on admission are shown in table $I$. All patients had thrombocytopenia and microangiopathic haemolytic : anaemia, in most cases severely. Eleven patients were anuric, four $T$ oliguric, and two had non-oliguric renal insufficiency. The mean $O$ duration of oliguria or anuria in patients who recovered their renal $\stackrel{\mathbb{Q}}{\mathscr{Q}}$ function was 20 days (range 10-37). Microscopical haematuria and $\mathbb{D}$ proteinuria were found in all non-anuric patients. The results of coagulation tests, including prothrombin time, activated partial thromboplastin time, thrombin time, fibrinogen concentration, and $ᄋ$ fibrinogen-fibrin degradation products, were normal in all cases.

After plasma infusion a haematological response was noted within 
TABLE I-Clinical and laboratory findings on admission

\begin{tabular}{|c|c|c|c|c|c|c|c|c|c|}
\hline $\begin{array}{l}\text { Case } \\
\text { No }\end{array}$ & Age & Sex & $\begin{array}{l}\text { Prodromal } \\
\text { illness }\end{array}$ & $\begin{array}{c}\text { Blood pressure } \\
(\mathrm{mm} \mathrm{Hg})\end{array}$ & $\begin{array}{l}\text { Urine output } \\
\left(\mathrm{ml} / \mathrm{m}^{2} / \text { day }\right)\end{array}$ & $\begin{array}{l}\text { Packed cell } \\
\text { volume }\end{array}$ & $\begin{array}{l}\text { Platelets } \\
\left(\times 10^{9} / 1\right)\end{array}$ & $\underset{(\mathrm{g} / 1)}{\text { Haptoglobin }}$ & $\begin{array}{c}\text { Blood urea } \\
\text { nitrogen }(\mathrm{mmol} / \mathrm{l})\end{array}$ \\
\hline $\begin{array}{l}1 \\
2 \\
3\end{array}$ & $\begin{array}{l}16 \mathrm{mth} \\
28 \mathrm{mth} \\
31 \mathrm{mth}\end{array}$ & $\begin{array}{l}\mathrm{F} \\
\mathrm{F} \\
\mathrm{M}\end{array}$ & $\begin{array}{l}\text { Diarrhoea } \\
\text { Diarrhoea } \\
\text { Respiratory } \\
\text { tract infection }\end{array}$ & $\begin{array}{l}160 / 110 \\
200 / 140 \\
160 / 110\end{array}$ & $\begin{array}{l}<200 \\
\text { None } \\
\text { None }\end{array}$ & $\begin{array}{l}0.28 \\
0.29 \\
0.19\end{array}$ & $\begin{array}{l}20 \\
15 \\
60\end{array}$ & $\begin{array}{c}0.5 \\
<0.2 \\
0.63\end{array}$ & $\begin{array}{l}38 \cdot 6 \\
32 \cdot 1 \\
42 \cdot 1\end{array}$ \\
\hline $\begin{array}{r}4 \\
5 \\
6 \\
7 \\
8 \\
9 \\
10 \\
11 \\
12 \\
13 \\
14 \\
15 \\
16 \\
17\end{array}$ & $\begin{array}{l}35 \mathrm{mth} \\
32 \mathrm{mth} \\
55 \mathrm{mth} \\
9 \mathrm{mth} \\
46 \mathrm{mth} \\
8 \mathrm{yr} \\
8 \mathrm{yr} \\
23 \mathrm{yr} \\
41 \mathrm{yr} \\
14 \mathrm{yr} \\
32 \mathrm{yr} \\
61 \mathrm{yr} \\
22 \mathrm{yr} \\
30 \mathrm{yr}\end{array}$ & $\begin{array}{l}M \\
M \\
M \\
M \\
F \\
M \\
F \\
M \\
M \\
M \\
F \\
M \\
M \\
M\end{array}$ & $\begin{array}{l}\text { Diarrhoea } \\
\text { Diarrhoea } \\
\text { Diarrhoea } \\
\text { Diarrhoea } \\
\text { Vomiting } \\
\text { Vomiting } \\
\text { Diarrhoea } \\
\text { None } \\
\text { Diarrhoea } \\
\text { None } \\
\text { Vomiting } \\
\text { None } \\
\text { None } \\
\text { None }\end{array}$ & $\begin{array}{l}120 / 70 \\
120 / 80 \\
110 / 80 \\
100 / 60 \\
100 / 60 \\
110 / 70 \\
110 / 50 \\
120 / 70 \\
230 / 150 \\
180 / 90 \\
240 / 150 \\
170 / 100 \\
220 / 120 \\
210 / 130\end{array}$ & $\begin{array}{c}\text { None } \\
<200 \\
\text { None } \\
\text { None } \\
\text { None } \\
1500 \\
<200 \\
700 \\
\text { None } \\
\text { None } \\
\text { None } \\
\text { None } \\
\text { None } \\
<200\end{array}$ & $\begin{array}{l}0 \cdot 21 \\
0 \cdot 11 \\
0 \cdot 25 \\
0 \cdot 22 \\
0 \cdot 25 \\
0 \cdot 18 \\
0 \cdot 18 \\
0 \cdot 25 \\
0 \cdot 27 \\
0 \cdot 22 \\
0 \cdot 22 \\
0 \cdot 23 \\
0 \cdot 22 \\
0.30\end{array}$ & $\begin{array}{r}40 \\
110 \\
11 \\
40 \\
36 \\
50 \\
25 \\
20 \\
30 \\
80 \\
85 \\
80 \\
87 \\
121\end{array}$ & $\begin{aligned} & 0.2 \\
&< 0.2 \\
&< 0.2 \\
&< 0.2 \\
&<0.2 \\
&<0.2 \\
&<0.2 \\
&<0.2 \\
&<0.2 \\
&<0.2 \\
&<0.2 \\
&<0.2 \\
&<0.2 \\
&<0.2\end{aligned}$ & $\begin{array}{l}19 \cdot 6 \\
77 \cdot 8 \\
49 \cdot 3 \\
17 \cdot 1 \\
26 \cdot 4 \\
21 \cdot 4 \\
39 \cdot 3 \\
16 \cdot 4 \\
39 \cdot 3 \\
22 \cdot 1 \\
42 \cdot 5 \\
22 \cdot 8 \\
48 \cdot 9 \\
26 \cdot 1\end{array}$ \\
\hline
\end{tabular}

Conversion: SI to traditional units-Blood urea nitrogen: $1 \mathrm{mmol} / 1 \approx 2.8 \mathrm{mg} / 100 \mathrm{ml}$.

TABLE II-Platelet count before and after plasma infusion in 17 patients with haemolytic uraemic syndrome

\begin{tabular}{|c|c|c|c|c|c|c|c|c|c|c|c|c|c|c|c|c|c|}
\hline Case No: & 1 & 2 & 3 & 4 & 5 & 6 & 7 & 8 & 9 & 10 & 11 & 12 & 13 & 14 & 15 & 16 & 17 \\
\hline $\begin{array}{l}\text { Platelets }\left(\times 10^{9} / 1\right) \text { : } \\
\text { On admission } \\
\text { After } 3 \text { days of plasma infusion }\end{array}$ & $\begin{array}{l}20 \\
80\end{array}$ & $\begin{array}{l}15 \\
60\end{array}$ & $\begin{array}{l}60 \\
80\end{array}$ & $\begin{array}{r}40 \\
100\end{array}$ & $\begin{array}{l}110 \\
140\end{array}$ & $\begin{array}{r}11 \\
150\end{array}$ & $\begin{array}{r}40 \\
120\end{array}$ & $\begin{array}{r}36 \\
100\end{array}$ & $\begin{array}{l}50 \\
85\end{array}$ & $\begin{array}{l}25 \\
40\end{array}$ & $\begin{array}{l}20 \\
75\end{array}$ & $\begin{array}{l}30 \\
78\end{array}$ & $\begin{array}{r}80 \\
225\end{array}$ & $\begin{array}{r}85 \\
255\end{array}$ & $\begin{array}{r}80 \\
220\end{array}$ & $\begin{array}{r}87 \\
155\end{array}$ & $\begin{array}{l}121 \\
205\end{array}$ \\
\hline
\end{tabular}

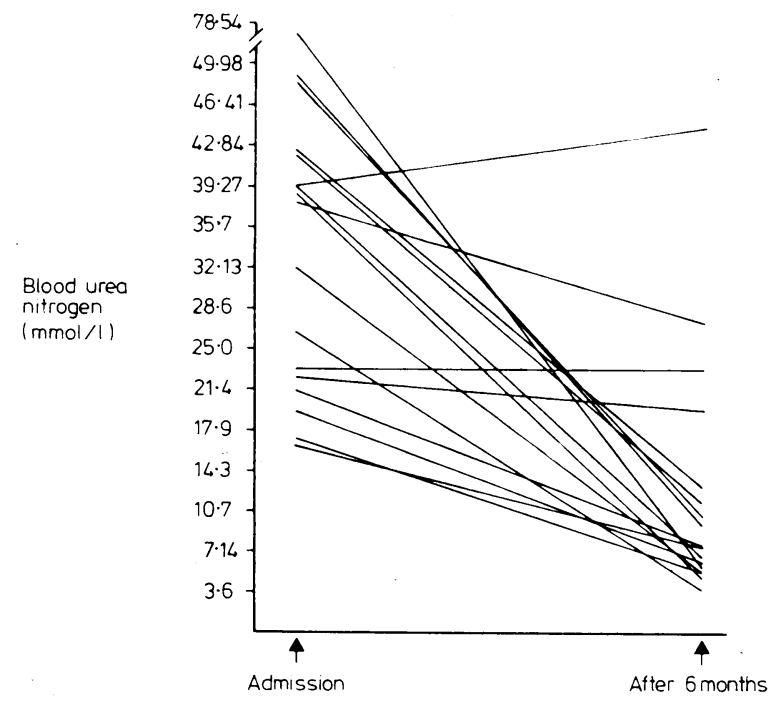

FIG 1-Changes of blood urea nitrogen in patients with haemolytic uraemic syndrome treated with plasma infusion after six months' follow-up.

Conversion: SI to traditional units-Blood urea nitrogen: 1 $\mathrm{mmol} / 1 \approx 2.8 \mathrm{mg} / 100 \mathrm{ml}$

three days in all but one patient (case 10; table II). This patient achieved full haematological remission over the next five weeks. The platelet count took a mean of three days (range 1-8) to return to normal. Renal response was observed in 14 patients after one to six weeks of treatment with plasma infusion. Seven children and two adults showed complete remission of the haemolytic uraemic syndrome after the first course of plasma infusion. Two patients suffered four episodes of early haematological and renal relapse, but all these episodes responded to the next course of treatment. One patient (case 11) had two recurrences 13 and 19 months after the first episode. Complete remission was obtained on all three occasions after plasma infusion. The only patient who apparently did not respond to plasma infusion achieved complete remission of the disease within four weeks of undergoing plasmapheresis. Six months after completion of the treatment two children and five adults showed residual chronic renal failure. Only two adults needed long-term haemodialysis, however. Fig 1 depicts the changes of renal function as measured by blood urea nitrogen.

During treatment with plasma three patients showed hypersensitivity reactions characterised by urticaria, chills, fever, and, in one patient (case 10), bronchospasm, which required withdrawal of treatment. Two patients developed hepatitis-one type $B$ and the other non-A, non-B-which was temporally related to the infusion of plasma. None of our patients had signs or symptoms of volume overload despite the large amounts of plasma we infused. Volume overload was prevented in patients undergoing dialysis by combining each infusion with adequate ultrafiltration.

\section{Discussion}

Plasma infusion has recently been proposed as a valuable form of treatment in thrombotic thrombocytopenic purpura. ${ }^{16} 18$ A preliminary report described two patients affected by haemolytic uraemic syndrome who responded to plasmapheresis and plasma infusion with improvement of haematological abnormalities and in one case with partial recovery of renal function. ${ }^{21}$ Our series of patients with haemolytic uraemic syndrome included 10 children and seven adults treated only with plasma infusion and supportive measures. A beneficial effect was observed in all but one case. The patient who failed to respond to plasma infusion recovered rapidly and completely after plasmapheresis.

Haemolytic uraemic syndrome in children is often described as a self-limiting form of the syndrome, usually with complete recovery, but anuria or prolonged oliguria has been associated with poor chances of survival and restoration of normal renal function. ${ }^{22-26}$ Gianantonio et $a l^{25}$ reported $25 \%$ mortality among patients with oliguria of more than 25 days' duration compared with an overall mortality of $6 \%$. The incidence of residual chronic renal insufficiency in patients with oliguria and anuria varies from $17 \%$ to $52 \%$ in different series. ${ }^{252728}$ Although nine of the 10 children in our series were anuric or oliguric, no child died or needed long-term haemodialysis. Two children still showed mild to moderate renal insufficiency after six months of follow-up.

Haemolytic uraemic syndrome in adults is generally severe, and recovery of renal function is uncommon. ${ }^{529}$ In a series recently reported by Morel-Maroger et al $50 \%$ of the patients died and $20 \%$ developed chronic renal failure requiring longterm haemodialysis. ${ }^{3}$ In our series all adults treated with plasma infusion obtained prompt haematological remission. In hypertensive patients blood pressure fell, making it possible to reduce their antihypertensive treatment. Normal blood pressure and platelet count seem to be of great importance, 
since several patients, particularly in the acute phase of the disease, die because of hypertensive or haemorrhagic complications. ${ }^{3}$ Two of our adult patients, whose renal biopsies showed pronounced arterial and arteriolar lesions, remained anuric and required long-term haemodialysis. In two others renal function recovered completely, whereas the remaining three adults had residual renal insufficiency.

A close temporal relationship was noted between plasma infusion and improvement of haematological values in all patients who benefited from the treatment. Previous studies had reported that the platelet count returned to normal after one to 23 days (mean nine days), depending on the severity of the initial thrombocytopenia. ${ }^{26} 27$ Thrombocytopenia responded to the treatment more rapidly in our patients, who showed a normal platelet count after one to eight days (mean three days). The effectiveness of plasma infusion was particularly evident in one patient who repeatedly relapsed as soon as plasma infusion was stopped and promptly responded once treatment was restarted (fig 2).

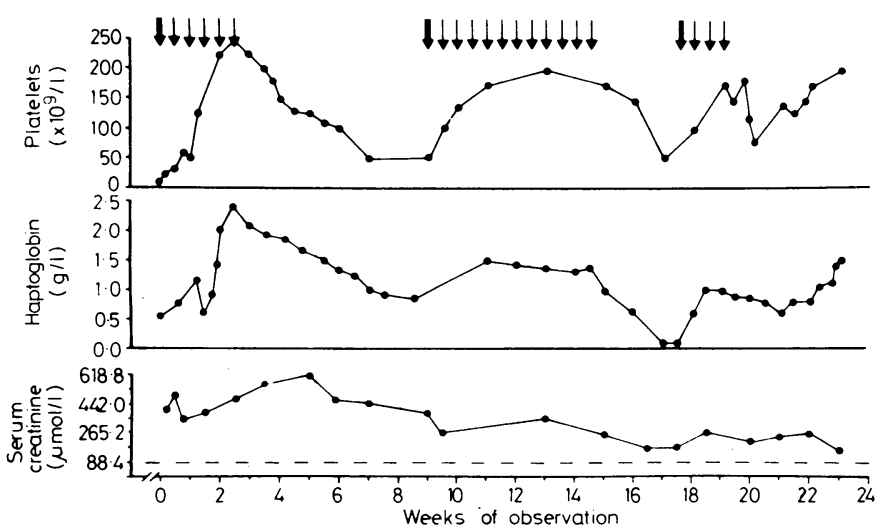

FIG 2-Case 3. Changes in platelet count and haptoglobin and serum creatinine concentrations, showing temporal relation between changes in these values and infusions of plasma.

Conversion: SI to traditional units-Creatinine: $1 \mu \mathrm{mol} / \mathrm{l} \approx 0.0113 \mathrm{mg} /$ $100 \mathrm{ml}$.

A likely explanation for the effectiveness of plasma infusion is that some deficiency in a normal plasma component plays a part in the pathogenetic sequence leading to thrombotic microangiopathy. ${ }^{23}$ Several studies have suggested that the missing factor might be the physiological stimulator of vascular prostacyclin. ${ }^{17} 19^{20} 30$ In patients who do not respond promptly to infusion the exchange procedure has the advantage of removing from the circulation aetiological factors and other material such as damaged red blood cell membranes and the products of platelet and white cell secretion. Careful clinical trials are warranted to establish the value of plasma infusion compared with other forms of treatment in haemolytic uraemic syndrome.

This study was supported by Associazione Bergamasca per lo Studio delle Malattie Renali and the Italian National Research Council. We thank Dr M B Donati and Dr G de Gaetano for critically reviewing the manuscript and Dr T Bertani for examining renal biopsy specimens.

Requests for reprints should be addressed to: Dr Giuseppe Remuzzi, Division of Nephrology, Ospedali Riuniti di Bergamo, 24100 Bergamo, Italy.

\section{References}

1 Habib R, Mathieu H, Royer P. Le syndrome hémolytique et urémique de l'enfant. Nephron 1967;4:139-72.

2 Gervais M, Richardson JB, Chin J, Drummond KN. Immunofluorescent and histologic findings in the hemolytic uremic syndrome. Pediatrics $1971 ; 47: 352-9$.
${ }^{3}$ Morel-Maroger L, Kanfer A, Solez K, Sraer JD, Richet G. Prognostic importance of vascular lesions in acute renal failure with microangiopathic hemolytic anemia (hemolytic uremic syndrome): clinicopathologic study in 20 adults. Kidney Int 1979;15:548-58.

4 Ponticelli C, Imbasciati E, Tarantino A, Graziani G, Redaelli G. Postpartum renal failure with microangiopathic haemolytic anaemia: longterm survival after anticoagulant therapy. Nephron 1972;9:27-41.

${ }^{5}$ Luke RG. Treatment of adult hemolytic uremic syndrome. $\mathrm{N} \mathrm{Engl} \mathrm{f} \mathrm{Med}$ 1976;294:396-9.

${ }^{6}$ Monnens L, Kleynen F, Van Munster P, Schretlen F, Bonnerman A. Coagulation studies and streptokinase therapy in the haemolytic uraemic syndrome. Helv Paediatr Acta 1972;27:45-54.

7 Stuart J, Winterborn MH, White RHR. Thrombolytic therapy in haemolytic uraemic syndrome. $\mathrm{Br}$ Med f 1974; iii :217-21.

${ }^{8}$ Katz J, Krawitz S, Sacks PV, Levin SE, Thomson P, Levin J, Metz J. Platelet, erythrocyte and fibrinogen kinetics in the hemolytic uremic syndrome of infancy. $\mathcal{F}$ Pediatr 1973;83:739-48.

9 Harker LA, Slichter SH. Platelet and fibrinogen consumption in man. N Engl f Med 1972;287:999-1005.

${ }^{10}$ Arenson GB, August CS. Preliminary report. Treatment of the hemolytic uremic syndrome with aspirin and dipyridamole. F Pediatr 1975;86: 957-61.

11 Thorsen CA, Rossi EC, Green D, Carone FA. The treatment of the hemolytic-uremic syndrome with inhibitors of platelet function. $A m \mathcal{F}$ Med 1979;66:711-6.

12 Kaplan BS, Drummond KN. The hemolytic uremic syndrome is a syndrome. N Engl f Med 1978;298:964-6.

${ }^{13}$ Bukowski RM, Hewlett JS, Harris JW, et al. Exchange transfusion in the treatment of thrombotic thrombocytopenic purpura. Semin Hematol 1976;13:219-32.

14 Pisciotta AY, Garthwaite T, Darin J, Aster RH. Treatment of thrombotic thrombocytopenic purpura by exchange transfusion. Am $\mathcal{F}$ Hematol $1977 ; 3: 73-82$.

15 Bukowski RM, King JW, Hewlett JS. Plasmapheresis in the treatment of thrombotic thrombocytopenic purpura. Blood 1977;50:413-7.

${ }^{16}$ Byrnes JJ, Khurana M. Treatment of thrombotic thrombocytopenic purpura with plasma. $N$ Engl f Med 1977;297:1386-9.

17 Remuzzi G, Misiani R, Marchesi D, et al. Haemolytic-uraemic syndrome: deficiency of plasma factor(s) regulating prostacyclin activity. Lancet 1978;ii :871-2.

18 Remuzzi G, Misiani R, Mecca G, de Gaetano G, Donati MB. Thrombotic thrombocytopenic purpura-a deficiency of plasma factor regulating platelet-vessel wall interaction? N Engl f Med 1978;299:311.

19 Machin SJ, Defreyn G, Chamone DAF, Vermylen J. Plasma 6 keto $\mathrm{PGF}_{1 \alpha}$ levels after plasma exchange in thrombotic thrombocytopenic purpura. Lancet 1980;i :661.

20 Jørgensen KA, Pedersen RS. Familial deficiency of prostacyclin production stimulating factor in the hemolytic uremic syndrome of childhood. Thromb Res (in press).

21 Remuzzi G, Misiani R, Marchesi D, et al. Treatment of the hemolytic uremic syndrome with plasma. Clin Nephrol 1979;12:279-84.

${ }^{22}$ Kaplan BS, Thompson PO, de Chadarevian JP. The hemolytic uremic syndrome. Pediatr Clin North Am 1976;23:761-77.

23 Anonymous. Plasma exchange in thrombotic thrombocytopenic purpura. Lancet $1979 ;$; :1065-6.

${ }^{24}$ Kaplan BS, Katz J, Krawitz S, Laurie A. An analysis of the results of therapy in 67 cases of the hemolytic-uremic syndrome. $f$ Pediatr 1971; $78: 420-5$.

25 Gianantonio CA, Vitacco M, Meudelaharzn F, Gallo GE, Sojo ET. The hemolytic uremic syndrome. Nephron 1973;11:174-92.

${ }^{26}$ Sorrenti LY, Lewy PR. The hemolytic uremic syndrome. Experience at a center in the Midwest. Am F Dis Child 1978;132:59-62.

${ }^{27}$ Dolislager D, Tune B. The hemolytic-uremic syndrome. Spectrum of severity and significance of prodromes. Am 7 Dis Child 1978;132:55-8.

${ }^{28}$ Donckerwolcke RA, Kuyten RH, Tiddens HA. Haemolytic-uraemic syndrome. Paediatrician 1975;4:27-40.

29 Goldstein MH, Churg J, Strauss L, Gribetz D. Hemolytic-uremic syn drome. Nephron 1979;23:263-72.

30 Remuzzi G, Mecca G, Livio M, et al. Prostacyclin generation by cultured endothelial cells in haemolytic uraemic syndrome. Lancet 1980; 656-7.

(Accepted 5 August 1982)

\section{Correction}

Are HLA antigens important in the development of alcohol-induced liver disease?

Two errors occurred in this paper by $R$ Faizallah et al (21 August, $p$ 533). In the second paragraph of the Subjects and method the second sentence should have read: "Tests for the presence of hepatitis $B$ surface antigen ( $\mathrm{HBsAg}$ ) and hepatitis $\mathrm{B}$ core antibody ( $\mathrm{HBcAb})$ were carried out in most cases." In the Results the last sentence should have read: "HBsAg was absent in all the patients tested, and only four were positive for $\mathrm{HBcAb}$ (by countercurrent immunoelectrophoresis), ...." 